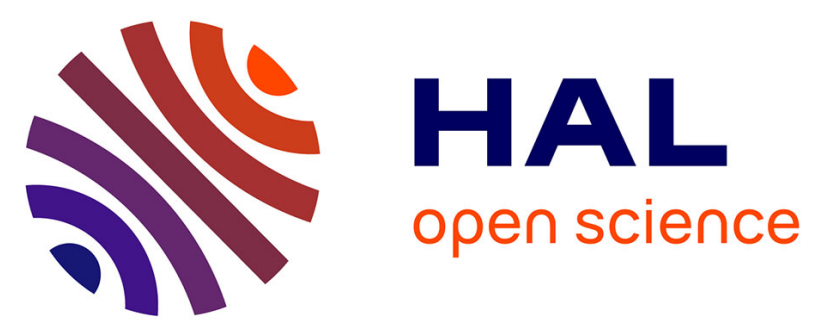

\title{
The Synergistic Effect of Chloride Ion and 1,5-Diaminonaphthalene on the Corrosion Inhibition of Mild Steel in 0.5 M Sulfuric Acid: Experimental and Theoretical Insights
}

Abdelqader El Guerraf, Abderrahim Titi, Karima Cherrak, Naoual Mechbal, Mohammed El Azzouzi, Rachid Touzani, Belkheir Hammouti, Hassane Lgaz

\section{To cite this version:}

Abdelqader El Guerraf, Abderrahim Titi, Karima Cherrak, Naoual Mechbal, Mohammed El Azzouzi, et al.. The Synergistic Effect of Chloride Ion and 1,5-Diaminonaphthalene on the Corrosion Inhibition of Mild Steel in 0.5 M Sulfuric Acid: Experimental and Theoretical Insights. Surfaces and Interfaces, 2018, 13, pp.168-177. 10.1016/j.surfin.2018.09.004 . hal-02162223

\section{HAL Id: hal-02162223 \\ https://hal.science/hal-02162223}

Submitted on 21 Jun 2019

HAL is a multi-disciplinary open access archive for the deposit and dissemination of scientific research documents, whether they are published or not. The documents may come from teaching and research institutions in France or abroad, or from public or private research centers.
L'archive ouverte pluridisciplinaire HAL, est destinée au dépôt et à la diffusion de documents scientifiques de niveau recherche, publiés ou non, émanant des établissements d'enseignement et de recherche français ou étrangers, des laboratoires publics ou privés. 


\title{
The Synergistic Effect of Chloride Ion and 1,5-Diaminonaphthalene on the Corrosion Inhibition of Mild Steel in 0.5 M Sulfuric Acid: Experimental and Theoretical Insights.
}

\author{
Abdelqader El Guerraf ${ }^{a}$, Abderrahim Titi $^{\mathrm{a}}$, Karima Cherrak ${ }^{\mathrm{a}}$, Naoual Mechbal ${ }^{\mathrm{a}}$, \\ Mohamed El Azzouzi ${ }^{\mathrm{a}}$, Rachid Touzani ${ }^{\mathrm{b}, \mathrm{c}}$, Belkheir Hammouti ${ }^{\mathrm{a}}$, Hassane Lgaz ${ }^{\mathrm{d}, \mathrm{e}, *}$ \\ a Laboratory of Applied Analytical Chemistry, Materials and Environment (LCA2ME), Faculty of Sciences, Mohammed Premier University, B.P. 4808, Oujda 60 046, \\ Morocco \\ ${ }^{\mathrm{b}}$ Multidisciplinary Faculty, Mohammed Premier University, B.P. 300, Selouane Nador 62 702, Morocco \\ ${ }^{\mathrm{c}}$ Laboratory of Applied Chemistry and Environment, COSTE, Faculty of sciences, Mohammed Premier University, B.P. 717, Oujda 60 000, Morocco \\ ${ }^{d}$ Laboratory of separation processes, Faculty of Science, University Ibn Tofail PO Box 242, Kenitra, Morocco \\ e Laboratory of Applied Chemistry and Environment, ENSA, Ibn Zohr University, PO Box 1136, Agadir, Morocco
}

\section{A R T I C L E I N F O}

\section{Keywords:}

Corrosion inhibition

Mild steel

$\mathrm{H}_{2} \mathrm{SO}_{4}$

DFT

Molecular dynamic simulations

\begin{abstract}
A B S T R A C T
The inhibition efficiency of 1,5-Diaminonaphthalene (1,5DNA) compound was studied by itself as well as in a mixture that included sodium chloride $(\mathrm{NaCl})$, noted $[1.5 \mathrm{DNA}]\left[\mathrm{Cl}^{-}\right]$, for mild steel in $0.5 \mathrm{M}$ sulfuric acid. Gravimetric, electrochemical techniques and computational chemistry calculations were utilized for the assessment of corrosion inhibition efficiency and explanation of the mechanism involved during the corrosion inhibition process. The results show that inhibition efficiencies on mild steel increase with increase in concentration of the inhibitor and enhancement in inhibition efficiency was observed on addition of sodium chloride due to synergism. This inhibition has been attributed to the stabilization of adsorbed inhibitor film and, consequently, increasing its inhibitive properties. The $[1.5 \mathrm{DNA}]\left[\mathrm{Cl}^{-}\right]$acts as mixed type inhibitor and the Nyquist curves show that with the increase in the concentration, the charge transfer resistance $\mathrm{R}_{\mathrm{ct}}$ increased. In addition, [1.5DNA] $\left[\mathrm{Cl}^{-}\right.$] obeyed Langmuir monolayer adsorption isotherm. Moreover, Molecular Dynamic Simulations and DFT calculations showed that $[1.5 \mathrm{DNA}]\left[\mathrm{Cl}^{-}\right]$owned a higher adsorption ability.
\end{abstract}

\section{Introduction}

Basically, the most popular steel used by companies is the mild steel; it is also usually the cheapest option, making it a great choice for industrial projects [1-5]. That's why it is easily exposed to the phenomenon of the corrosion due to the use of the acid solutions $(\mathrm{HCl}$ and $\mathrm{H}_{2} \mathrm{SO}_{4}$ ) in several industrial processes such as cleaning and descaling [6]. The organic compounds with $\mathrm{N}, \mathrm{S}$, and or $\mathrm{O}$ atoms are widely used as effective corrosion inhibitors for several industrial metals in corrosive media. Additionally, functional electronegative groups and $\pi$ electrons in triple or conjugated double bonds enable inhibitors to adsorb to the metal surface and form protective complex layers [7-9]. Bentiss et al. [10], El Azhar et al. [11] and Elkadi et al. [12] have studied many inhibitors which contain nitrogen on the minimization of the corrosion of steel in $\mathrm{H}_{2} \mathrm{SO}_{4}$ and $\mathrm{HCl}$ using chemical and electro- chemical methods. In recent years, some attempts were made to further improve the inhibition efficiency of organic corrosion inhibitors of maximally, proposing them as efficient compounds for steel protection. The synergism between an inhibitor and other ions such as iodide has been extensively studied by many authors [13-15]. The information about the synergistic effect of chloride ion was rarely reported.

The theoretical study of the structure-reactivity relationship of corrosion inhibitors is an innovative and promising approach. This approach not only explores the intrinsic electronic properties of each inhibitor but also allows their modes of adsorption to be modeled on the metal surface [16-18].

In the present study, the effect of the addition of 1,5Diaminaphthalene, shown in Fig. 1, and their synergism with $0.1 \mathrm{M}$ $\mathrm{NaCl}$ on the corrosion inhibition of mild steel in $0.5 \mathrm{M}$ sulfuric acid was studied using chemical, electrochemical and theoretical calculations. 


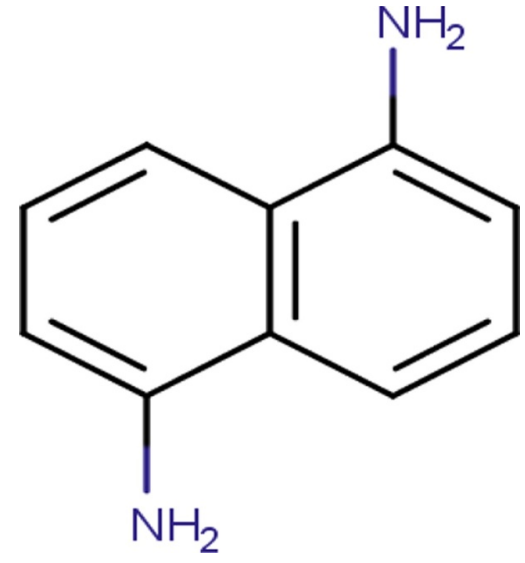

Fig. 1. 1,5-Diaminonaphthalene.

\section{Experimental}

\subsection{Materials}

The experiments were performed with mild steel have the following composition: $\mathrm{Fe}$ (99.21\%),Si (0.38\%), C (0.21\%), P (0.09\%), Mn $(0.05 \%), \mathrm{S}(0.05 \%), \mathrm{Al}(0.01 \%)$. The steel sample were grinded with emery paper Sic (90, 240, 400, 600 and 1000), washed with distilled water, acetone and finally dried to eliminate the liquid.

\subsection{Solution}

Test solutions were prepared immediately prior to use from $97 \%$ $\mathrm{H}_{2} \mathrm{SO}_{4}$ (analytical grade, Sigma Chemical, St. Louis MO, USA) diluted in distilled water, and then the 1,5-Diaminonaphthalene was dissolved in this solution to prepare the corresponding concentration in $\mathrm{mol} \mathrm{L}^{-1}$, a solution containing $\mathrm{H}_{2} \mathrm{SO}_{4}$ alone was taken as blank. The range of 1,5DAN concentration was $10^{-6} \mathrm{M}$ to $10^{-3} \mathrm{M}$ while the concentration of $\mathrm{NaCl}$ was $0.1 \mathrm{M} \mathrm{NaCl}$. All the experiments were carried out in triplicate with an experimental errors not exceed 3\% (data not shown).

\subsection{Weight loss method}

Gravimetric method has been realized using steel samples that have a size of $1 \times 1 \times 0.2 \mathrm{~cm}^{3}$. The time of the immersion was $6 \mathrm{~h}$ at $308 \mathrm{~K}$ using a thermostat in beakers which contained $50 \mathrm{~mL}$ of $0.5 \mathrm{M} \mathrm{H}_{2} \mathrm{SO}_{4}$ alone, then with the addition of 1,5DAN and finally with the addition of the system 1,5DAN/0.1 M NaCl. $6 \mathrm{~h}$ later, we bring the sample; wash it, dry it and weighed with a precision scale. The following equations were used to calculate the corrosion rates $\left(\mathrm{C}_{\mathrm{R}}\right)$ and the inhibition efficiency $\left(\eta_{W L}(\%)\right)[19]$ :

$C_{\mathrm{R}}=\left[\frac{W_{\mathrm{b}}-W_{\mathrm{a}}}{A t}\right]$

$\eta_{W L}(\%)=\left[\frac{C_{\mathrm{R}}^{\circ}-C_{\mathrm{R}}}{C_{\mathrm{R}}^{\circ}}\right] \times 100$

where $W_{\mathrm{b}}$ and $W_{\mathrm{a}}$ are the weight of the sample before and after immersion in the different solutions, $C_{\mathrm{R}}^{\circ}$ and $C_{\mathrm{R}}$ are the corrosion rate without and with addition of inhibitor respectively, $A$ is the area of the sample $\left(\mathrm{cm}^{2}\right)$ and $\mathrm{t}$ is the time of exposure (h).

\subsection{Electrochemical measurements}

Tafel curves were achieved using a Potentiostat/Galvanostat(PGZ $100)$ related to a computer with analysis software model (Volta master 4). The experiment were realized with a cell having three electrode, mild steel is as working electrode, saturated calomel as the reference electrode and the auxiliary electrode was platinum (Pt). Mild steel electrode surface was prepared like we did in gravimetric method and immersed in various concentrations of the solution for $30 \mathrm{~min}$ to stabilize the electrochemical system. The Tafel plots were realized with the change of the potential from -800 to $-200 \mathrm{mV} / \mathrm{SCE}$ and with a scan rate of $1 \mathrm{mV} / \mathrm{s}$. The percentage protection efficiency $\eta_{\mathrm{PDP}}(\%)$ is defined as [20]:

$\eta_{\mathrm{PDP}}(\%)=\left[1-\frac{i_{\text {corr }}}{i_{\text {corr }}^{\circ}}\right] \times 100$

$i_{\text {corr }}^{\circ}$ and $i_{\text {corr }}$ are the current density without and with addition of inhibitor in $0.5 \mathrm{M}$ sulfuric acid.

The Nyquist presentation in the EIS method were performed with the same material already used in realization of the Tafel plots with a range of frequencies $(10 \mathrm{mHz}-100 \mathrm{KHz})$ at corrosion potential and an amplitudes of $10 \mathrm{mV}$. With the following equation we can calculate the inhibition efficiency $\left(\eta_{E I S}(\%)\right)[21]$ :

$\eta_{E I S}(\%)=\left[\frac{R_{\mathrm{p}(\mathrm{inh})}-R_{\mathrm{p}}}{R_{\mathrm{p}(\mathrm{inh})}}\right] \times 100$

where $R_{\mathrm{p}(\mathrm{inh})}$ and $R_{\mathrm{p}}$ are the polarization resistances with and without addition of inhibitor in $0.5 \mathrm{M}$ sulfuric acid.

\subsection{DFT calculations}

Quantum chemical calculations were obtained using Gaussian program package, module version 9.0 [22]. The calculation was performed using a basis set denoted by 6-31 G (d, p) [23,24]. All quantum calculations were carried out in aqueous phase using Self-Consistent Reaction Field (SCRF) theory, with Polarized Continuum Model (PCM) [25]. The ionization energy and the electronic affinity were determined by the values of the energies of the HOMO and LUMO orbital using the following Eqs. (5) and (6) [26]:

$I P=-E_{\mathrm{HOMO}}$

$E A=-E_{\mathrm{LUMO}}$

Mulliken electronegativity $(\chi)$ and Absolute hardness ( $\eta$ ) can be approximated using $[27,28]$ :

$\chi=\frac{I P+E A}{2}$

$\eta=\frac{I P-E A}{2}$

The number of transferred electrons $(\Delta \mathrm{N})$ is calculated by application of the Pearson method using the equation [29]:

$\Delta N=\frac{\phi-\chi_{\text {inh }}}{2\left(\eta_{F e}+\eta_{\text {inh }}\right)}$

where $\varphi=4.82$ is the work function used as the appropriate measure of electronegativity of iron, and $\eta_{F e}=0[30,31]$.

\subsection{Molecular dynamics (MD) simulations}

Molecular dynamic simulations studies were carried out using Materials studio package [32]. The behavior of the 1,5DAN molecule on the Fe (110) surface was simulated in a $10 \times 10$ super cell using the COMPASS force field and the Smart algorithm. Fe (110) surface has been preferred as it has a packed surface and high stability [33]. MD simulation was performed under $303 \mathrm{~K}$, NVT ensemble, with a time step of $1 \mathrm{fs}$ and simulation time of $2000 \mathrm{ps}$ in a simulation box of $\left(24.82 \times 24.82 \times 35.69 \AA^{3}\right)$. More detail of MD simulation is referenced from our published articles [34,35]. 
Table 1

The parameters calculated by weight loss method for $1,5 \mathrm{DAN}$ and $1,5 \mathrm{DAN}+0.1 \mathrm{M} \mathrm{NaCl}$ in $0.5 \mathrm{M} \mathrm{H}_{2} \mathrm{SO}_{4}$ solution at $308 \mathrm{~K}$.

\begin{tabular}{|c|c|c|c|c|}
\hline Inhibitor & Concentration (M) & $\mathrm{C}_{\mathrm{R}}\left(\mathrm{mg} \cdot \mathrm{cm}^{-2} \cdot \mathrm{h}^{1}\right)$ & $\eta_{W L}(\%) \%$ & $\theta$ \\
\hline $\mathrm{H}_{2} \mathrm{SO}_{4}$ & 0.5 & 12.4 & - & - \\
\hline $\mathrm{NaCl}$ & 0.1 & 4.466 & 63.9 & 0.639 \\
\hline \multirow[t]{6}{*}{ 1,5DAN } & $10^{-3}$ & 9.042 & 27 & 0.27 \\
\hline & $5 \times 10^{-4}$ & 9.426 & 23.9 & 0.239 \\
\hline & $10^{-4}$ & 11.335 & 8.5 & 0.085 \\
\hline & $5 \times 10^{-5}$ & 11.376 & 8.2 & 0.082 \\
\hline & $10^{-5}$ & 11.642 & 6.1 & 0.061 \\
\hline & $10^{-6}$ & 12.245 & 1.2 & 0.012 \\
\hline \multirow[t]{6}{*}{$1,5 \mathrm{DAN}+0.1 \mathrm{M} \mathrm{NaCl}$} & $10^{-3}$ & 1.063 & 91.4 & 0.914 \\
\hline & $5 \times 10^{-4}$ & 3.479 & 71.9 & 0.719 \\
\hline & $10^{-4}$ & 3.756 & 69.7 & 0.697 \\
\hline & $5 \times 10^{-5}$ & 3.859 & 68.8 & 0.688 \\
\hline & $10^{-5}$ & 4.335 & 65 & 0.65 \\
\hline & $10^{-6}$ & 4.362 & 64.8 & 0.648 \\
\hline
\end{tabular}

Table 2

The influence of temperature on Gravimetric parameters for mild steel immersed in $0.5 \mathrm{M}$ sulfuric acid with and without addition of $1,5 \mathrm{DAN}$ and $0.1 \mathrm{M}$ NaCl.

\begin{tabular}{|c|c|c|c|c|c|}
\hline \multirow[t]{2}{*}{$\mathrm{T}(\mathrm{K})$} & \multirow[t]{2}{*}{ Concentration (M) } & \multicolumn{2}{|l|}{$1,5 \mathrm{DAN}$} & \multicolumn{2}{|l|}{$1,5 \mathrm{DAN}+\mathrm{NaCl}$} \\
\hline & & $C_{R}\left(\mathrm{mg} \cdot \mathrm{cm}^{-2} \cdot \mathrm{h}^{1}\right)$ & $\eta_{\mathrm{WL}} \%$ & $C_{R}\left(\mathrm{mg} \cdot \mathrm{cm}^{-2} \cdot \mathrm{h}^{1}\right)$ & $\eta_{\mathrm{WL}} \%$ \\
\hline \multirow[t]{2}{*}{308} & Blanc & 10.9301 & & & \\
\hline & $10^{-3}$ & 5.5923 & 48.83 & 0.2728 & 97.5 \\
\hline \multirow[t]{2}{*}{318} & Blanc & 22.9891 & & & \\
\hline & $10^{-3}$ & 14.1207 & 38.576 & 0.5732 & 97.5 \\
\hline \multirow[t]{2}{*}{328} & Blanc & 50.7996 & & & \\
\hline & $10^{-3}$ & 33.2923 & 34.46 & 1.1759 & 97.68 \\
\hline \multirow[t]{2}{*}{338} & Blanc & 88.9004 & & & \\
\hline & $10^{-3}$ & 59.9041 & 32.61 & 1.72872 & 98.05 \\
\hline
\end{tabular}

\section{Results and discussion}

\subsection{Weight loss measurements}

\subsubsection{Effect of concentration}

Table 1 and presents the corrosion rate $\left(C_{R}\right)$ and the efficiencies $\left(\eta_{W L}(\%)\right)$ of single $1,5 \mathrm{DAN}$, single $0.1 \mathrm{M} \mathrm{NaCl}$ and the system containing both of $\mathrm{NaCl}$ and 1,5DAN calculated from the gravimetric method after $6 \mathrm{~h}$ of immersion. It is clear that $C_{R}$ decreases when 1,5DAN concentration increase, and is also evident that $\eta_{W L}(\%)$ increase with increasing in 1,5DAN concentration. At 1,5DAN concentration equal $10^{-3} \mathrm{M}$ alone in the solution, the maximum of efficiency was $27 \%$, which shows that the single inhibitor cannot protect effectively the corrosion of the metal in $0.5 \mathrm{M}$ sulfuric acid. The results also indicate that the values of the efficiency increase considerably after the addition of constant $\mathrm{NaCl}$ concentration $(0.1 \mathrm{M})$ and a maximum efficiency increase to reach $91 \%$. We conclude that the combination of inhibitor and $0.1 \mathrm{M} \mathrm{NaCl}$ is more effective for reducing the phenomenon of corrosion of the metal, meaning that it is possible to exit a synergistic effect between $\mathrm{NaCl}$ and 1,5DAN.

\subsubsection{Effect of temperature}

The corrosion reaction and the inhibition mechanism can be effected by the factor of the temperature, so it is necessary to study the effect of this parameter. The effect of the temperature on the corrosion inhibition property of $1,5 \mathrm{DAN}$ was performed with weight loss method and with a range of $308-338 \mathrm{~K}$ with and without addition of various concentrations of 1,5DAN and $0.1 \mathrm{M} \mathrm{NaCl}$ (Table 2).

The first experience without $\mathrm{NaCl}$, when the temperature increases, the inhibition efficiencies decrease, this behavior is associated to desorption of 1,5DAN from the metal surface, because the increase of the temperature accelerates the corrosion phenomena [36]. However, the addition of $0.1 \mathrm{M} \mathrm{NaCl}$ makes the efficiencies practically constant in the

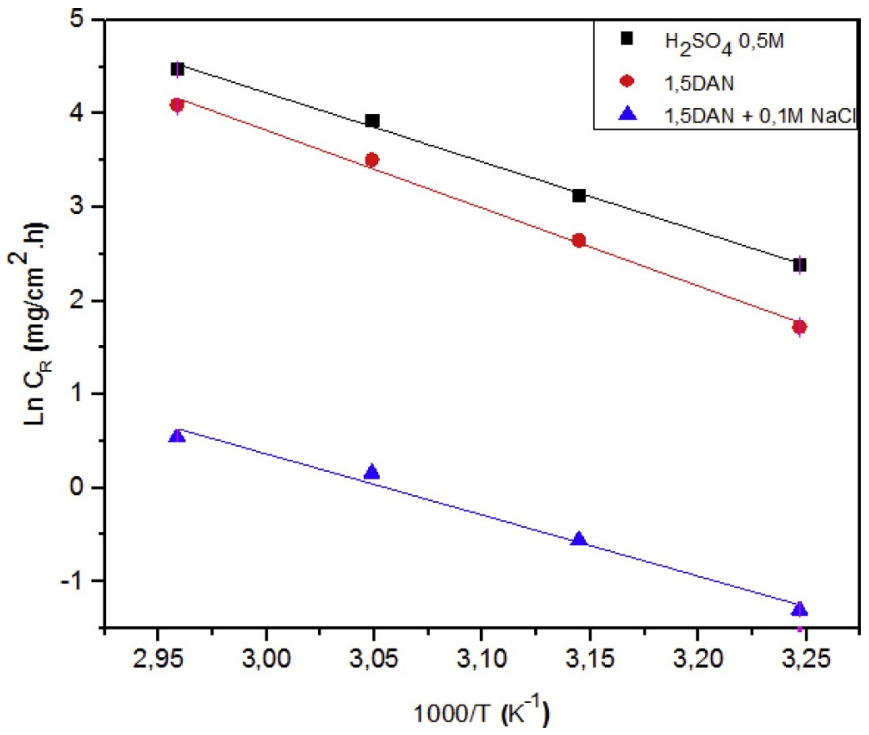

Fig. 2. Arrhenius curves for mild steel with and without addition of 1,5DAN and $0.1 \mathrm{M} \mathrm{NaCl}$ in $0.5 \mathrm{M}$ sulfuric acid.

temperature range explored. These results show that the presence of $\mathrm{NaCl}$ increase the stabilization of the complex already adsorbed on the surface [37].

\subsubsection{The activation parameters}

The temperature dependency of current density can be best represented by the Arrhenius and transition state equations [38,39]: 


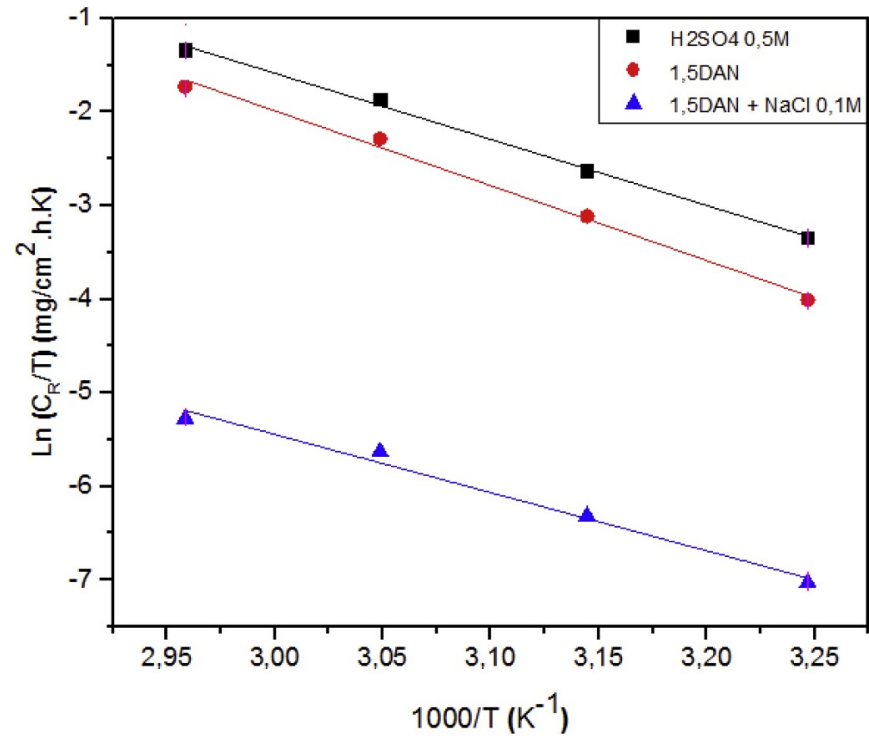

Fig. 3. Arrhenius curves for mild steel with and without addition of $1,5 \mathrm{DAN}$ and $0.1 \mathrm{M} \mathrm{NaCl}$ in $0.5 \mathrm{M}$ sulfuric acid.

$C_{R}=A \exp \left(\frac{-E_{a}}{R T}\right)$

$C_{R}=\frac{R T}{N h} \exp \left(\frac{\Delta S_{a}}{R}\right) \exp \left(-\frac{\Delta H_{a}}{R T}\right)$

$\Delta S_{\mathrm{a}}$ is the change in entropy of activation, $\Delta \mathrm{Ha}$ is the change in enthalpy of activation, $E_{a}$ is the apparent activation energy, $R$ is the gas constant, $\mathrm{A}$ is the Arrhenius pre-exponential factor, $\mathrm{h}$ is Plank's constant and $\mathrm{N}_{\mathrm{a}}$ is Avogadro's number.

The values of $E_{\mathrm{a}}$ were calculated by linear regression between $\ln$ $\left(\mathrm{C}_{\mathrm{R}}\right)$ and $1 / \mathrm{T}$ (Fig. 2). Fig. 3 shows that the Arrhenius plots of $\mathrm{Ln}\left(C_{R} / \mathrm{T}\right)$ versus $1 /$ T gave straight lines with slope $\left(-\Delta \mathrm{H}_{\mathrm{a}} / \mathrm{R}\right)$ and intercept (Ln R/ $\left.\mathrm{Nh}+\Delta \mathrm{S}_{\mathrm{a}} / \mathrm{R}\right)$ from where $\Delta \mathrm{H}_{\mathrm{a}}$ and $\Delta \mathrm{S}_{\mathrm{a}}$ values were calculated.

Table 3 show that the calculated value of Ea for the corrosion of steel in $0.5 \mathrm{M}$ sulfuric acid is about $61 \mathrm{KJ} \mathrm{mol}^{-1}$. But, the value of this parameter with the addition of $10^{-} 3 \mathrm{M}$ of $1,5 \mathrm{DAN}$ is about $69 \mathrm{KJ} \mathrm{mol}^{-1}$, which is higher than that for blank, when we add $0.1 \mathrm{M}$ $\mathrm{NaCl}$ to our inhibitor we see that the apparent activation energy decrease compared to the blank. The higher value of $E_{\mathrm{a}}$ in presence of $1,5 \mathrm{DAN}$ indicates that more energy barrier is required for the corrosion reaction to occur [40], while the lower value observed after addition of $0.1 \mathrm{M} \mathrm{NaCl}$ is attributed to the higher adsorption of the $[1.5 \mathrm{DNA}]\left[\mathrm{Cl}^{-}\right]$ on the mild steel surface mainly via strong chemical interaction. If we look again to the Arrhenius equation above, we can easily see that the corrosion phenomenon is controlled by two factor, the first is Ea and the second A (pre-exponential factor). So we tried to calculate this factor and the results show that it increase remarkably with the addition of $0.1 \mathrm{M} \mathrm{NaCl}$, so we can conclude that the inhibition process in the complex containing both of $1,5 \mathrm{DAN}$ and $\mathrm{NaCl}$ is mostly dominated by the pre-exponential factor $[41,42]$.

The large negative number of the entropies $\left(\Delta S_{a}\right)$ indicates a decrease in disordering [43], and the negative signs of the enthalpies

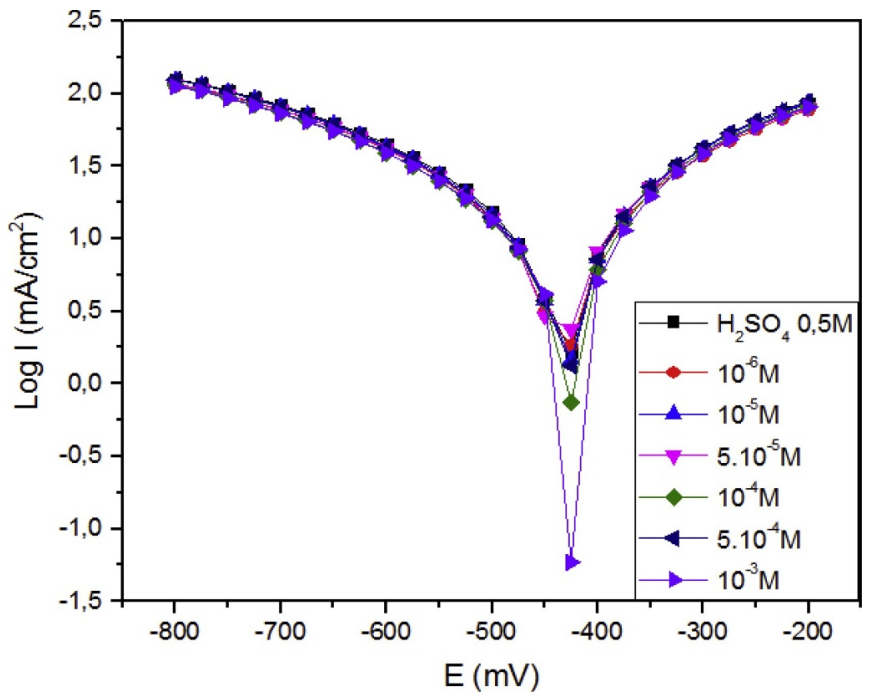

Fig. 4. Tafel curves of mild steel in $0.5 \mathrm{M} \mathrm{H}_{2} \mathrm{SO}_{4}$ with and without addition of 1,5 DAN.

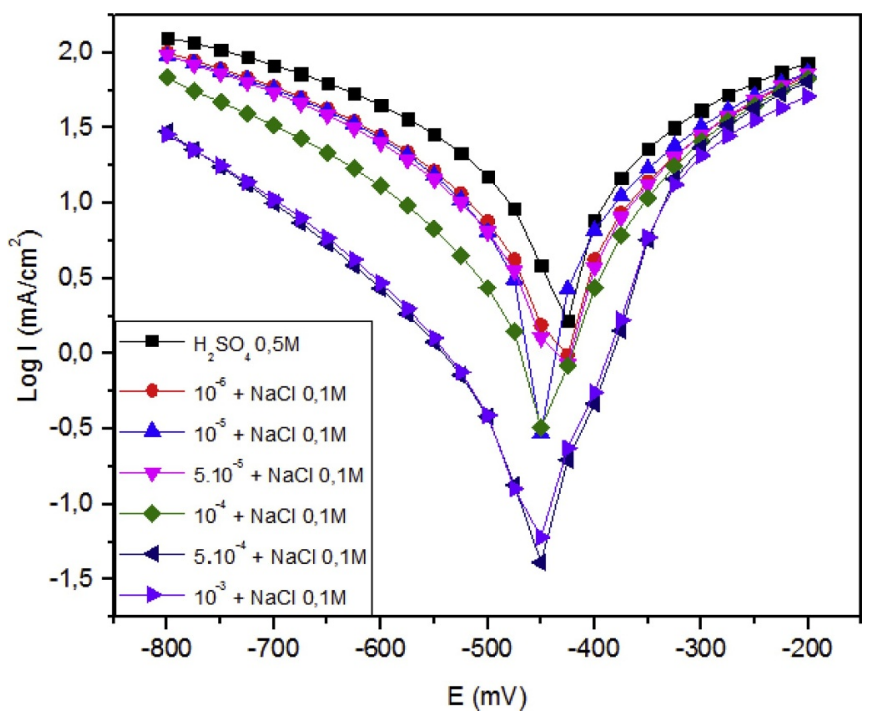

Fig. 5. Tafel curves of mild steel in $0.5 \mathrm{M} \mathrm{H}_{2} \mathrm{SO}_{4}$ with and without addition of $1,5 \mathrm{DAN}$ and $0.1 \mathrm{M} \mathrm{NaCl}$.

$\left(\Delta H_{a}\right)$ show the exothermic process of the adsorption. We can see, on the other hand, that $E_{a}$ and $\Delta H_{a}$ vary in the same way, which satisfies this relationship [44]:

$\mathrm{Ea}-\Delta \mathrm{H}_{\mathrm{a}}=\mathrm{RT}$

\subsection{Polarization potentiodynamic results}

The Tafel plots of mild steel in $0.5 \mathrm{M} \mathrm{H}_{2} \mathrm{SO}_{4}$ with and without addition of 1,5DAN and the complex [1.5DNA] $\left[\mathrm{Cl}^{-}\right]$are shown in Figs. 4 and 5, while electrochemical data obtained from the curves are

Table 3

The activation parameters for mild steel in $0.5 \mathrm{M}$ sulfuric acid with and without addition of $1,5 \mathrm{DAN}$ and $0.1 \mathrm{M} \mathrm{NaCl}$.

\begin{tabular}{|c|c|c|c|c|c|}
\hline Inhibitor & $\mathrm{Ea}\left(\mathrm{Kj}_{\mathrm{mol}} \mathrm{mo}^{-1}\right)$ & Pre-exponential factor $\left(\mathrm{mg} \mathrm{m}^{-2} \mathrm{~h}^{-1}\right)$ & $\Delta \mathrm{H}_{\mathrm{a}}^{\circ}\left(\mathrm{KJ} \mathrm{mol}^{-1}\right)$ & $\Delta \mathrm{S}_{\mathrm{a}}^{\circ}\left(\mathrm{KJ} \mathrm{mol}^{-1} \mathrm{~K}^{-1}\right)$ & $\mathrm{Ea}-\Delta \mathrm{H}_{\mathrm{a}}^{\circ}\left(\mathrm{KJ} \mathrm{mol}^{-1}\right)$ \\
\hline Blank & 61.32 & $2.7990 \times 10^{11}$ & 58.64 & -34.73 & 2.68 \\
\hline 1,5DAN & 69.10 & $3.1181 \times 10^{12}$ & 66.42 & -14.70 & 2.68 \\
\hline $1,5 \mathrm{DAN}+0.1 \mathrm{MNaCl}$ & 54.29 & $4.6867 \times 10^{8}$ & 51.61 & -87.85 & 2.68 \\
\hline
\end{tabular}


Table 4

Polarization data of the mild steel in $0.5 \mathrm{M}$ sulfuric acid with and without addition of 1,5DAN and $0.1 \mathrm{M} \mathrm{NaCl}$.

\begin{tabular}{|c|c|c|c|c|c|c|}
\hline Inhibitor & Concentration (M) & $\mathrm{E}_{\text {corr }}(\mathrm{mV} / \mathrm{SCE})$ & $\beta c\left(m V \operatorname{dec}^{-1}\right)$ & $\beta \mathrm{a}\left(\mathrm{mV} \mathrm{dec}{ }^{-1}\right)$ & $i_{\text {corr }}\left(\mathrm{mA} \mathrm{cm}^{-2}\right)$ & $\eta_{\text {Tafel }}(\%)$ \\
\hline $\mathrm{H}_{2} \mathrm{SO}_{4}$ & 0.5 & -436 & -333 & 287 & 13.51 & - \\
\hline \multirow[t]{3}{*}{$\mathrm{NaCl}$} & 0.1 & -434 & -286 & 245 & 8.70 & 35.58 \\
\hline & $10^{-3}$ & -425 & -262 & 190 & 8.49 & 37.11 \\
\hline & $5 \times 10^{-4}$ & -431 & -280 & 227 & 10.92 & 19.17 \\
\hline \multirow[t]{4}{*}{ 1,5DAN } & $10^{-4}$ & -428 & -312 & 233 & 11.11 & 17.77 \\
\hline & $5 \times 10^{-5}$ & -431 & -301 & 235 & 11.75 & 13.04 \\
\hline & $10^{-5}$ & -434 & -303 & 265 & 11.78 & 12.81 \\
\hline & $10^{-6}$ & -432 & -315 & 262 & 13.15 & 2.68 \\
\hline \multirow[t]{6}{*}{ 1,5DAN + $0.1 \mathrm{M} \mathrm{NaCl}$} & $10^{-3}$ & -456 & -175 & 86 & 0.42 & 96.85 \\
\hline & $5 \times 10^{-4}$ & -458 & -174 & 92 & 0.47 & 96.50 \\
\hline & $10^{-4}$ & -442 & -212 & 134 & 2.34 & 82.61 \\
\hline & $5 \times 10^{-5}$ & -434 & -222 & 168 & 4.54 & 66.35 \\
\hline & $10^{-5}$ & -434 & -264 & 213 & 6.67 & 50.64 \\
\hline & $10^{-6}$ & -447 & -271 & 230 & 7.46 & 44.73 \\
\hline
\end{tabular}

presented in Table 4. Table 4 shows that with the increase in 1,5DAN concentration, the corrosion current density $\left(i_{\text {corr }}\right)$ decrease, this decrease is really marked with the addition of $\mathrm{Cl}^{-}$.

Also we can see a very small change in the position of the cathodic and anodic plots. According to some published papers, if the change of the potential $\mathrm{E}_{\text {corr }}$ was $>85 \mathrm{mV} / \mathrm{SCE}$ the inhibitor can be classified as cathodic or anodic type $[45,46]$. This work shows that $1,5 \mathrm{DAN}$ is a mixed inhibitor in $0.5 \mathrm{M}$ sulfuric acid. We can see also from the results that the efficiency of the system [1.5DNA $]\left[\mathrm{Cl}^{-}\right]$is large compared to 1,5DAN alone, these results also confirm the possibility of the existence of a strong synergism between 1,5DAN and $\mathrm{NaCl}$.

\subsection{Electrochemical impedance spectroscopy}

For studying the impedance parameters of mild steel specimens in $0.5 \mathrm{M} \mathrm{H}_{2} \mathrm{SO}_{4}$ with different concentrations of 1,5DAN and [1.5DNA] $\left[\mathrm{Cl}^{-}\right]$inhibitor, EIS measurements were carried out. The results are shown in Fig. 6 and Table 5. The Nyquist diagrams describe two phenomenon, the first one show that the corrosion of our metal in the corrosive solution is controlled by the process of the charge transfer (capacitive loop appearing at HF) and the second indicate the phenomenon of adsorption and relaxation of the present species controlling the anodic process (small inductive appearing at LF) [47]. Further, it can be seen from Fig. 6 that the diameter of the impedance spectra in presence of inhibitor is much higher than that in the uninhibited solution, and this increase became more pronounced as inhibitor concentration increased, especially, after addition of $\mathrm{NaCl}$, which suggests that the studied inhibitor adsorbed on the metal surface and a protective film is formed $[48,49]$. Fig. 7 shows the equivalent electric circuit models which represent the interface solution/metal. These circuits contain a CPE (constant phase element) which is used to take into account the inhomogeneities in the surface resulted from impurities and formation of porous layers [50]. The circuits contain also a resistance of the charge transfer $R_{c t}$, a resistance of the solution Rs, and an inductance resistor, $\mathrm{R}_{\mathrm{L}}$ related with an inductance $\mathrm{L}$ explain the small inductive appearing at LF [51]. The impedance of a CPE is expressed as [52]:

$Z_{C P E}=\frac{1}{Q(j \omega)^{n}}$

where $\mathrm{Q}$ is the CPE constant and CPE exponent, $\mathrm{n}$ is the phase shift which can be used as a measure of surface inhomogeneity [53]; $j$ is an imaginary number and $\omega$ is the angular frequency in rad.s ${ }^{-1}$. However, the values of $C_{d 1}$ were computed from the $Q$ and $n$ values, using Eq. (17) [54]:

$C_{\mathrm{dl}}=\sqrt[n]{Q \times R_{c t}^{1-\mathrm{n}}}$

Table 5 represents the impedance data in $0.5 \mathrm{M}$ sulfuric acid with
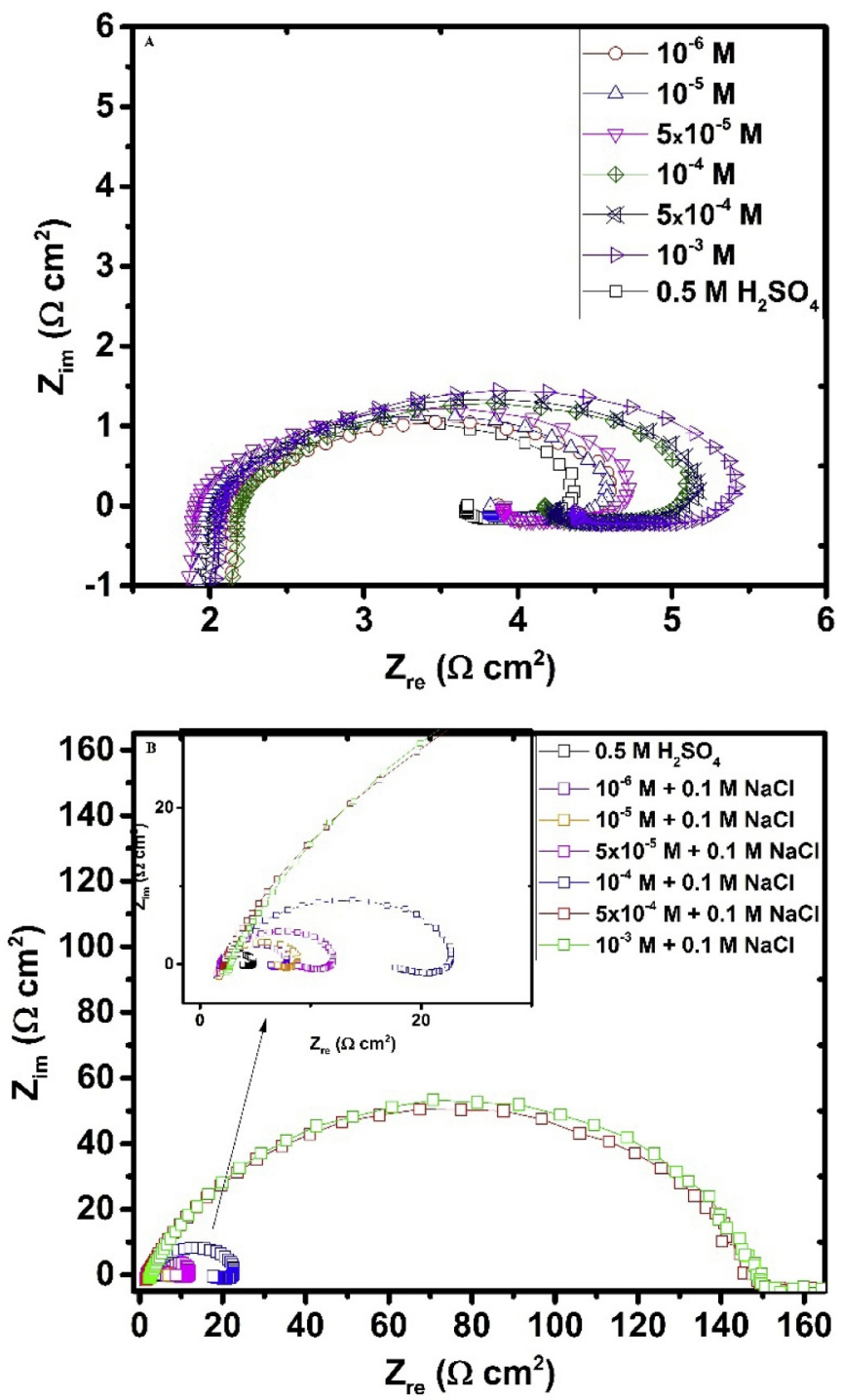

Fig. 6. Nyquist plot for mild steel in $0.5 \mathrm{M}$ sulfuric acid without and with addition of (A) 1,5DAN and (B) 1,5DAN $+\mathrm{NaCl}$.

and without addition of 1,5DAN alone and in combination with $0.1 \mathrm{M}$ $\mathrm{NaCl}$. The results presented in Table 5 shows that $\mathrm{R}_{\mathrm{ct}}$ and $\eta_{E I S}(\%)$ increase when 1,5DAN concentration increase, this increase is more important with the addition of the chloride ion. We can explain the increase in $R_{c t}$ by the formation of a protective complex in the surface. In 
Table 5

EIS parameters for corrosion of the metal in $0.5 \mathrm{M}$ sulfuric acid with and without addition of inhibitor and $0.1 \mathrm{M} \mathrm{NaCl}$.

\begin{tabular}{|c|c|c|c|c|c|c|c|c|c|}
\hline Inhibitor & Conc. (M) & $\mathrm{R}_{\mathrm{s}}\left(\Omega \mathrm{cm}^{2}\right)$ & $\operatorname{Rp}\left(\Omega \mathrm{cm}^{2}\right)$ & $\mathrm{Q}\left(\mathrm{s}^{\mathrm{n}} \mu \Omega^{-1} \mathrm{~cm}^{-2}\right)$ & $\mathrm{n}$ & $\mathrm{R}_{\mathrm{L}}\left(\Omega \mathrm{cm}^{2}\right)$ & $\mathrm{L}\left(\mathrm{H} \mathrm{cm}^{-2}\right)$ & $\mathrm{C}_{\mathrm{dl}}\left(\mu \mathrm{F} \mathrm{cm}^{-2}\right)$ & $\eta_{E I S}(\%)$ \\
\hline $\mathrm{H}_{2} \mathrm{SO}_{4}$ & 0.5 & 1.1 & 2.34 & 20.6 & 0.86 & 0.72 & 1.11 & 870 & - \\
\hline \multirow[t]{3}{*}{$\mathrm{NaCl}$} & 0.1 & 1.7 & 6.12 & 6.6 & 0.85 & 0.76 & 1.15 & 249 & 61 \\
\hline & $10^{-3}$ & 1.9 & 3.5 & 12.6 & 0.82 & 1.14 & 1.31 & 383 & 33 \\
\hline & $5 \times 10^{-4}$ & 2.1 & 3.4 & 13.4 & 0.87 & 0.89 & 1.11 & 598 & 31 \\
\hline \multirow[t]{4}{*}{ 1,5DAN } & $10^{-4}$ & 2.3 & 3.1 & 13.7 & 0.89 & 1.43 & 0.97 & 697 & 24 \\
\hline & $5 \times 10^{-5}$ & 1.7 & 2.9 & 15.1 & 0.88 & 1.09 & 1.19 & 720 & 19 \\
\hline & $10^{-5}$ & 1.6 & 2.7 & 17.3 & 0.87 & 1.21 & 0.87 & 775 & 13 \\
\hline & $10^{-6}$ & 2.8 & 2.3 & 19.4 & 0.87 & 1.03 & 1.17 & 864 & -1.7 \\
\hline \multirow[t]{6}{*}{$1,5 \mathrm{DAN}+0.1 \mathrm{M} \mathrm{NaCl}$} & $10^{-3}$ & 2.6 & 146.8 & 1.2 & 0.89 & - & - & 72 & 98 \\
\hline & $5 \times 10^{-4}$ & 2.7 & 144 & 1.8 & 0.85 & - & - & 94 & 98 \\
\hline & $10^{-4}$ & 2.0 & 19.4 & 5.8 & 0.84 & 3.5 & 0.95 & 246 & 88 \\
\hline & $5 \times 10^{-5}$ & 1.7 & 8.7 & 7.1 & 0.86 & 3.4 & 0.89 & 310 & 73 \\
\hline & $10^{-5}$ & 1.9 & 7.8 & 10.2 & 0.85 & 3.1 & 0.77 & 432 & 69 \\
\hline & $10^{-6}$ & 1.8 & 6.3 & 15.5 & 0.82 & 2.1 & 0.98 & 561 & 62 \\
\hline
\end{tabular}

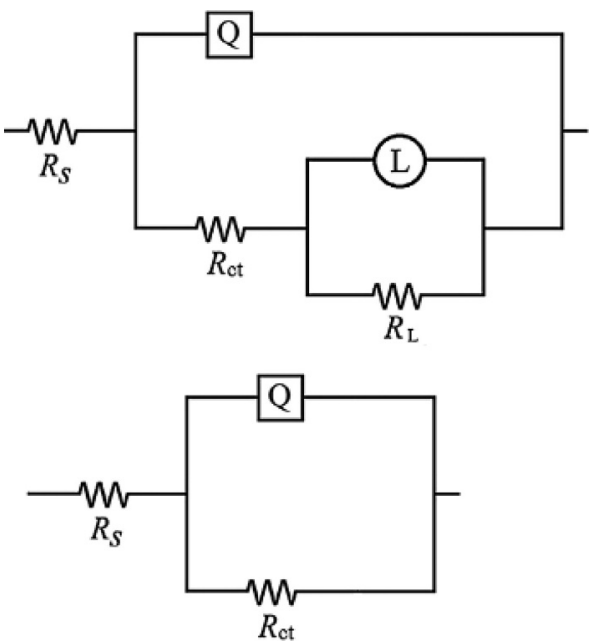

Fig. 7. Equivalent electric circuits for EIS measurements.

another case the $C_{d l}$ values decrease with increasing the 1,5DAN concentration, this phenomenon can be attributed to the adsorption of the inhibitor, leading to the formation of an insoluble film [55]. The comparison of the results of EIS and potentiodynamic polarization method indicate the same tendency.

\section{Thermodynamic parameters of adsorption}

To better understand the inhibitor/metal interaction and the adsorption of our inhibitor, we tried to use various isotherms such as Langmuir [56], Freundlich [57], Temkin [58] and Frumkin [59]. The corresponding isotherm for our inhibitor is obtained from the comparison of the correlation coefficients $\left(\mathrm{R}^{2}\right)$ presented in Table 6 .

The results show that Langmuir isotherm have the biggest coefficient values, so we can conclude that 1,5DAN alone and with addition of $\mathrm{NaCl}$ accords to the Langmuir isotherm in $0.5 \mathrm{M}$ sulfuric acid (Fig. 8). The equation corresponding to Langmuir adsorption isotherm is:

$\frac{C_{\text {inh }}}{\theta}=\frac{1}{K_{\text {ads }}}+C_{\text {inh }}$

With the following equation, the standard free energy of adsorption

Table 6

The correlation coefficient $\mathrm{R}^{2}$ for each isotherm.

\begin{tabular}{lllll}
\hline & Langmuir & Freundlich & Temkin & Frumkin \\
\hline 1,5DAN + 0.1MNaCl & 0.98452 & 0.61047 & 0.57134 & 0.34803 \\
1,5DAN & 0.96257 & 0.95084 & 0.81951 & 0.4855
\end{tabular}

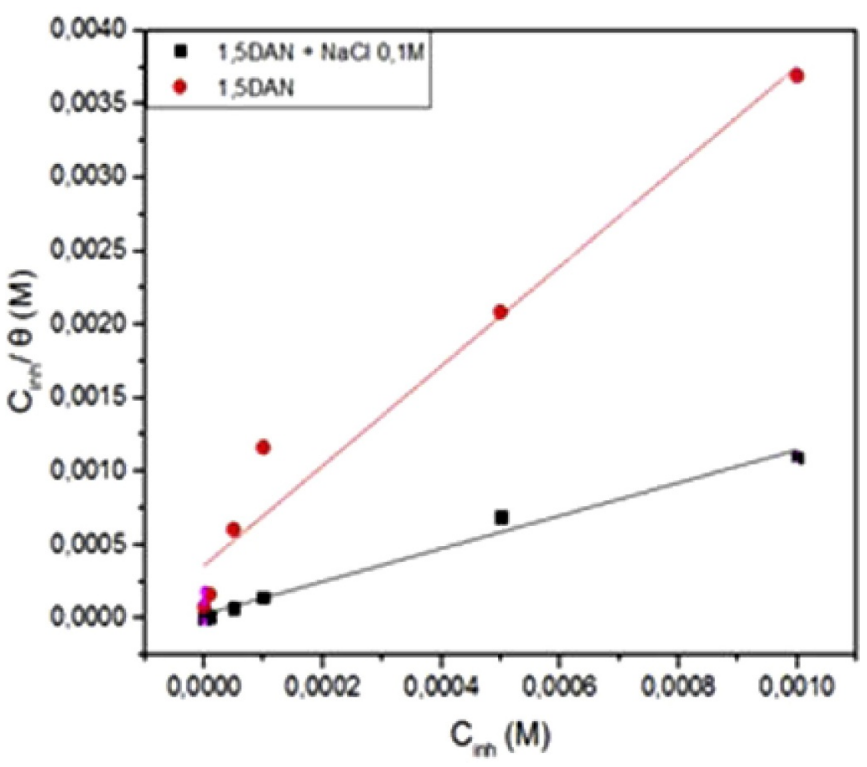

Fig. 8. Langmuir isotherm for mild steel immersed in $0.5 \mathrm{M}$ sulfuric acid with and without addition of $1,5 \mathrm{DAN}$ and $0.1 \mathrm{M} \mathrm{NaCl}$.

Table 7

The thermodynamic parameters obtained for 1,5DAN and the system [1.5DNA] $\left[\mathrm{Cl}^{-}\right]$.

\begin{tabular}{lll}
\hline Inhibitor & $\mathrm{K}_{\mathrm{ads}}(\mathrm{L} / \mathrm{mol})$ & $\Delta G_{\mathrm{ads}}^{\circ}(\mathrm{kJ} / \mathrm{mol})$ \\
\hline 1,5DAN + 0.1MNaCl & $37,462.16$ & -37.23 \\
$\mathbf{1 , 5 D A N}$ & 2790.84 & -30.59 \\
\hline
\end{tabular}

$\Delta G_{\text {ads }}^{\circ}$ has been calculated [60]:

$\Delta G_{\mathrm{ads}}^{\circ}=-R T \ln \left(K_{\mathrm{ads}} \times 55.5\right)$

$\mathrm{R}$ is the gas constant, $\mathrm{T}$ is the temperature and 55.5 is the concentration of the water in the solution in $\mathrm{mol} \mathrm{L}^{-1}$. The strong positives values of $\mathrm{K}_{\mathrm{ads}}$ (Table 7) indicate the important interactions in the interface inhibitor/metal. According to some authors, a value around $-20 \mathrm{~kJ} / \mathrm{mol}$ or lower of $\Delta G_{\text {ads }}^{\circ}$ indicate that we have an adsorption with electrostatic interaction (physisorption), on the other hand a value around or higher than $-40 \mathrm{~kJ} / \mathrm{mol}$ indicate that we have a charge sharing between the inhibitor and the surface of the mild steel (chemisorption) [8]. In our case, the $\Delta G_{\text {ads }}^{\circ}$ values are between $-20 \mathrm{~kJ} / \mathrm{mol}$ and $-40 \mathrm{~kJ} / \mathrm{mol}$ so the inhibitor are both physisorbed and chemisorbed, and we can conclude also from the negatives values that the reaction of the adsorption of 1,5DAN is spontaneous. 
Table 8

Synergism parameters of $1,5 \mathrm{DAN}$ and $0.1 \mathrm{M} \mathrm{NaCl}$ in $0.5 \mathrm{M} \mathrm{H}_{2} \mathrm{SO}_{4}$.

\begin{tabular}{|c|c|}
\hline Concentration of $1,5 \mathrm{DAN}$ with $0.1 \mathrm{M} \mathrm{NaCl}$ & Synergism parameter \\
\hline $10^{-3}$ & 17.63 \\
\hline $5 \times 10^{-4}$ & 18.94 \\
\hline $10^{-4}$ & 2.92 \\
\hline $5 \times 10^{-5}$ & 1.48 \\
\hline $10^{-5}$ & 1.20 \\
\hline $10^{-6}$ & 1.09 \\
\hline
\end{tabular}

\section{The synergistic effect of the system [1.5DNA] $\left[\mathrm{Cl}^{-}\right]$}

The reason why we used $\mathrm{NaCl}$ in our work is that generally halide ions like the chlorure can help the inhibitor to better adsorb in the surface of the metal [61]. Table 8 shows the parameters of synergism that we can calculate with the relationship given by Aramaki and Hackerman [62]:

$\mathrm{S}_{\mathrm{a}}=\frac{1-\mathrm{a}_{1+2}}{1-\mathrm{a}_{1+2}^{\prime}}$

$\mathrm{a}_{1+2}=\left(\mathrm{a}_{1}+\mathrm{a}_{2}\right)-\left(\mathrm{a}_{1} \cdot \mathrm{a}_{2}\right)$

where $\mathrm{a}_{1}$ is the surface coverage by $\mathrm{NaCl}, \mathrm{a}_{2}$ is the surface coverage by $1,5 \mathrm{DAN}$ and $\mathrm{a}_{1+2}^{\prime}$ is the surface coverage by both $\mathrm{NaCl}$ and $1,5 \mathrm{DAN}$. According to Aramaki and Hackerman, when $S_{a}<1$ we have a competitive adsorption between the inhibitor and the halide ion, however, when $S_{a}>1$ we are in the presence of synergistic effect. The surface coverage values were evaluated using the inhibition efficiencies obtained from the EIS techniques.

$S_{a}$ values given in Table 8 are mostly superior to the unit, so we can conclude that the improve of the inhibition efficiency when we add $\mathrm{NaCl}$ to 1,5DAN can be explained by the existence of a synergistic effect between these two. Regarding the mechanism we suggest that $\mathrm{Cl}^{-}$is adsorbed in first place on the surface after that the protonated form of the inhibitor will be adsorbed by the interaction of coulomb with $\mathrm{Cl}^{-}$ already adsorbed on surface. After this first process, the inhibitor in its neutral form shares its electron with metal surface, i.e. chemisorption.

\section{DFT calculations}

Fig. 9 represents the geometry optimization, the density distribution of the highest occupied molecular orbital (HOMO) and density distribution of the lowest unoccupied molecular orbital (LUMO) of $1,5 \mathrm{DAN}$, while the quantum chemical parameters $\mathrm{E}_{\mathrm{HOMO}}, \mathrm{E}_{\mathrm{LUMO}}, \Delta \mathrm{E}$,
Table 9

The quantum parameters for 1,5DAN calculated using DFT method.

\begin{tabular}{ll}
\hline Quantum parameters & Value \\
\hline $\mathbf{E}_{\text {LUMo }}(\mathrm{ev})$ & -0.794572 \\
$\mathbf{E}_{\text {HOMo }}(\mathrm{ev})$ & -5.494794 \\
$\Delta \mathbf{E}_{\text {gap }}(\mathrm{ev})$ & 4.70022 \\
$\boldsymbol{\mu}(\mathrm{Debye})$ & 0.0006 \\
$\mathbf{I}(\mathrm{ev})$ & 5.494794 \\
$\mathbf{A}(\mathrm{ev})$ & 0.794572 \\
$\boldsymbol{\eta}(\mathbf{e v})$ & 2.350111 \\
$\chi_{\text {inh }}(\mathrm{ev})$ & 3.144683 \\
$\boldsymbol{\Delta} \mathbf{N}$ & 0.820241 \\
\hline
\end{tabular}

dipole $\mu \Delta \mathrm{N}$...etc. are given in Table 9 .

The highest occupied molecular orbital energy, $E_{\text {номо }}$ is related to the tendency of the inhibitor to donate electrons while $\mathrm{E}_{\mathrm{LUMO}}$, the lowest unoccupied molecular orbital, indicates the tendency of the inhibitor to accept electrons [19]. The difference between the energy HOMO and LUMO is called $\Delta \mathrm{E}_{\text {gap }}$, this parameter is very useful in the quantum chemistry and can be used to predict the stability of the formed complex, generally the decrease in the energy gap is related to an increase in the inhibition efficiency [8]. In the present study, it can be seen that, generally, the band gap energy of our inhibitor is higher compared to some of efficient corrosion inhibitors previously published $[8,63]$, which can give us some explanation of the lower inhibition efficiency of tested compound. The number of transferred electrons $(\Delta \mathrm{N})$ means also electron-donating ability, give us information of the ability of the inhibitor to donate electrons (if $\Delta N>1$ ), the positive value of this parameter is related to the ability of tested compound to donate electron to metal surface $[20,21]$.

\section{MD simulations}

MD simulations can provide a good insight into the interaction between inhibitor and iron surface [8,21]. MD simulations are first performed in a vacuum slab without any solvation effect, and the corresponding stable configuration for 1,5DAN is presented in Fig. 10 both in vacuum and in presence of solvent. In the stable configuration, 1,5DAN molecule is nearly parallel to the Fe (110) plane and exhibits an approximately planar conformation. The interactions and binding energies are calculated using Eqs. (8) and (9) [64]:

$E_{\text {interaction }}=E_{\text {total }}-\left(E_{\text {surface+solution }}+E_{\text {inhibitor }}\right)$

$E_{\text {Binding }}=-E_{\text {interaction }}$

\section{Optimized molecular structure}

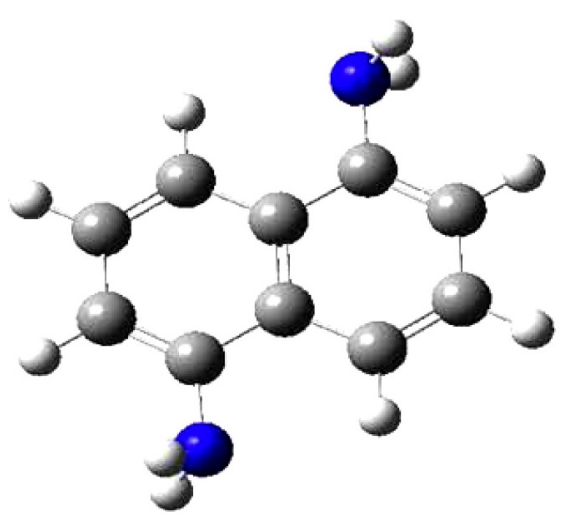

HOMO

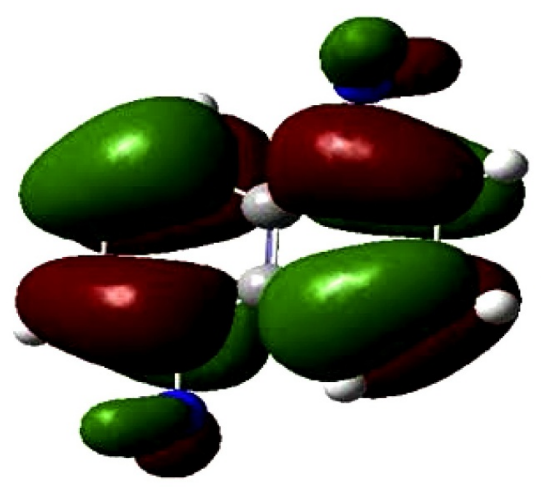

LUMO

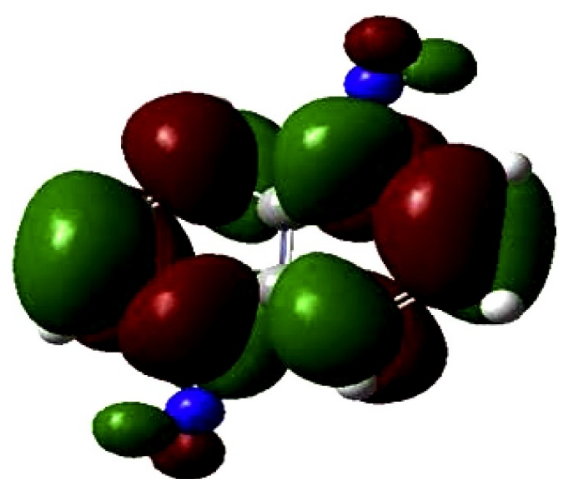

Fig. 9. Optimized molecular structure, HOMO and LUMO of1,5DAN. 


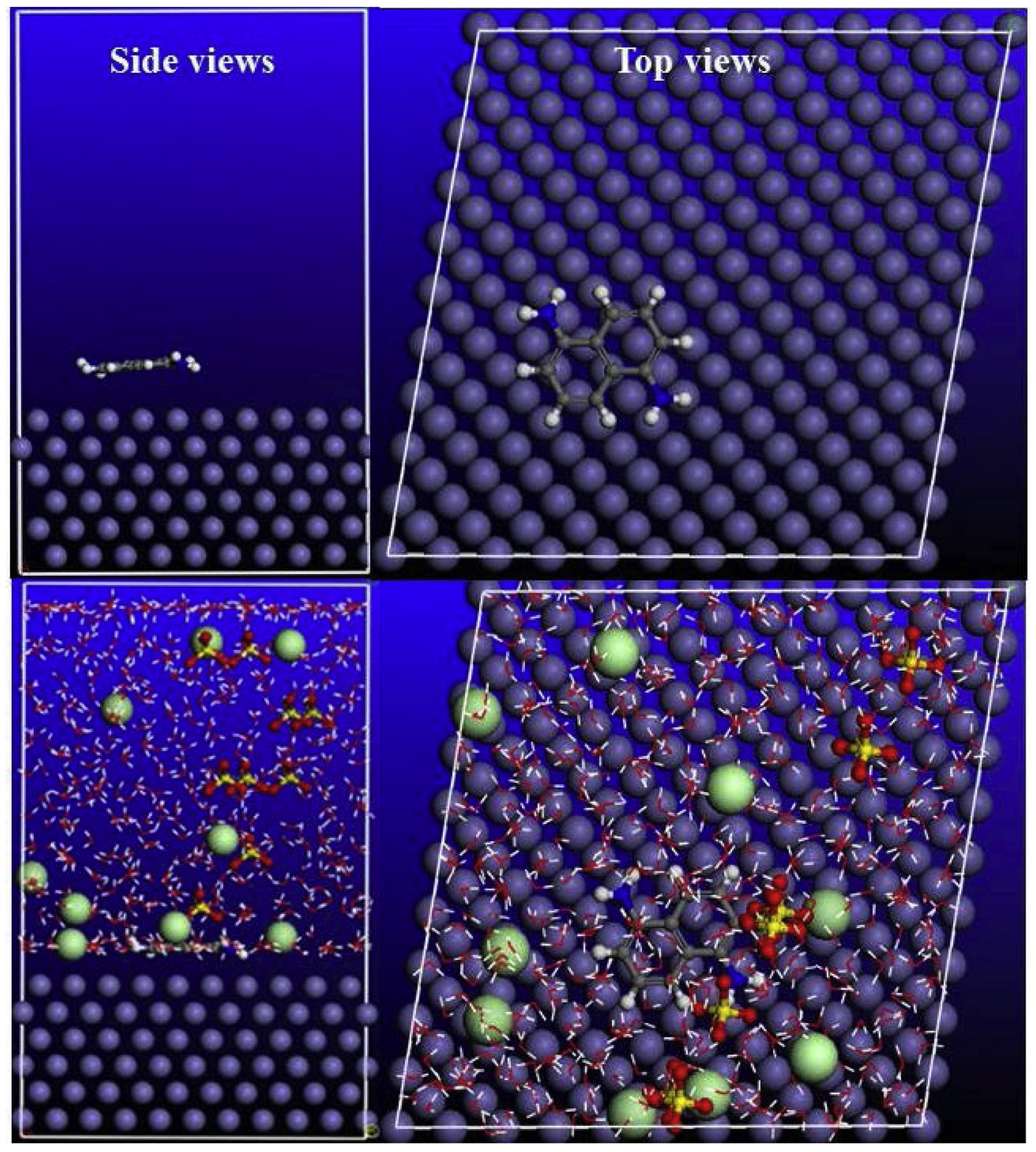

Fig. 10. Equilibrium configurations of 1.5DNA in vacuum and in aqueous systems.

where $E_{\text {total }}$ is the total energy of the entire system $E_{\text {surface }}+$ solution referred to the total energy of Fe (110) surface and solution without the inhibitor and $E_{\text {inhibitor }}$ represents the total energy of inhibitor.

In vacuum, the interaction energy value of 1,5DAN adsorbed on $\mathrm{Fe}$ (110) is $-104.7 \mathrm{KJ} / \mathrm{mol}$. It can be seen that the $E_{\text {int }}$ value is generally lower, which is in agreement with our previous conclusions in experimental section. Therefore, solvation effect is taken into consideration in the MD simulations in order to study the adsorption of tested compound in presence of all concerned species. A parallel mode is observed for the adsorption of 1,5DAN in the presence of solvation. The interaction energy between [1.5DNA] $\left[\mathrm{Cl}^{-}\right]$and $\mathrm{Fe}(110)$ plane in the aqueous systems is more negative $(-241.8 \mathrm{KJ} / \mathrm{mol})$ than that in vacuum, indicating that $[1.5 \mathrm{DNA}]\left[\mathrm{Cl}^{-}\right]$can more tightly adsorb on iron surface and achieve a better corrosion inhibition effectiveness [9,19]. 


\section{Conclusions}

In this work, the inhibition efficiency of $1,5 \mathrm{DAN}$ was studied using gravimetric and electrochemical method; the following conclusions can be noted:

$\checkmark$ The efficiency of 1,5DAN becomes higher when we increase the concentration but the inhibitor steel ineffective.

$\checkmark$ The efficiency of 1,5DAN becomes more important when we add $0.1 \mathrm{M} \mathrm{NaCl}$ to our solution.

$\checkmark$ The temperature affects the processes of the adsorption in the absence of $\mathrm{NaCl}$, however, with the addition of $\mathrm{NaCl}$ to our system the inhibition efficiency increase and remains constant.

$\checkmark$ The adsorption of $1,5 \mathrm{DAN}$ alone or with $\mathrm{NaCl}$ in $0.5 \mathrm{M} \mathrm{H}_{2} \mathrm{SO}_{4}$ follows the Langmuir isotherm.

$\checkmark$ The Tafel plots show that 1,5DAN is a mixed type inhibitor in $0.5 \mathrm{M}$ sulfuric acid.

$\checkmark$ The synergism parameters values clearly show that the corrosion inhibition by the combination of 1,5DAN and chloride ion is synergistic in nature.

$\checkmark$ In MD simulations, the interaction of [1.5DNA] $\left[\mathrm{Cl}^{-}\right]$in aqueous system with the iron surface is stronger than that of vacuum system, resulting better blocking effect of inhibitor for the mild steel surface.

\section{Conflict of interest}

None.

\section{References}

[1] S. Vikneshvaran, S. Velmathi, Adsorption of L-Tryptophan-derived chiral Schiff bases on stainless steel surface for the prevention of corrosion in acidic environment: experimental, theoretical and surface studies, Surf. Interfaces 6 (2017) 134-142, https://doi.org/10.1016/j.surfin.2017.01.001.

[2] R.G. Toro, P. Calandra, B. Cortese, T. de Caro, M. Brucale, A. Mezzi, F. Federici, D. Caschera, Argon and hydrogen plasma influence on the protective properties of diamond-like carbon films as barrier coating, Surf. Interfaces 6 (2017) 60-71, https://doi.org/10.1016/j.surfin.2016.11.009.

[3] E. Ech-chihbi, M.E. Belghiti, R. Salim, H. Oudda, M. Taleb, N. Benchat, B. Hammouti, F. El-Hajjaji, Experimental and computational studies on the in hibition performance of the organic compound " 2 -phenylimidazo [1,2-a]pyrimidine-3-carbaldehyde" against the corrosion of carbon steel in $1.0 \mathrm{M} \mathrm{HCl}$ solution, Surf. Interfaces 9 (2017) 206-217, https://doi.org/10.1016/j.surfin.2017.09. 012.

[4] N. Palaniappan, L.R. Chowhan, S. Jothi, I.G. Bosco, I.S. Cole, Corrosion inhibition on mild steel by phosphonium salts in $1 \mathrm{M} \mathrm{HNO} 3$ aqueous medium, Surf. Interfaces 6 (2017) 237-246, https://doi.org/10.1016/j.surfin.2016.10.003.

[5] S.E. Kaskah, M. Pfeiffer, H. Klock, H. Bergen, G. Ehrenhaft, P. Ferreira, J. Gollnick, C.B. Fischer, Surface protection of low carbon steel with N-acyl sarcosine derivatives as green corrosion inhibitors, Surf. Interfaces 9 (2017) 70-78, https://doi.org/ 10.1016/j.surfin.2017.08.002.

[6] K.R. Ansari, M.A. Quraishi, A. Singh, Corrosion inhibition of mild steel in hydrochloric acid by some pyridine derivatives: an experimental and quantum chemical study, J. Ind. Eng. Chem. 25 (2015) 89-98, https://doi.org/10.1016/j.jiec.2014.10. 017.

[7] Y. El Aoufir, Y. El Bakri, H. Lgaz, A. Zarrouk, R. Salghi, I. Warad, Y. Ramli, A. Guenbour, E.M. Essassi, H. Oudda, Understanding the adsorption of benzimidazole derivative as corrosion inhibitor for carbon steel in 1M HCl: experimental and theoretical studies, J. Mater. Environ. Sci. 8 (2017) 3290-3302.

[8] H. Lgaz, K. Subrahmanya Bhat, R. Salghi, Shubhalaxmi, S. Jodeh, M. Algarra, B. Hammouti, I.H. Ali, A. Essamri, Insights into corrosion inhibition behavior of three chalcone derivatives for mild steel in hydrochloric acid solution, J. Mol. Liq. 238 (2017) 71-83, https://doi.org/10.1016/j.molliq.2017.04.124.

[9] Y. El Aoufir, J. Sebhaoui, H. Lgaz, Y. El Bakri, A. Zarrouk, F. Bentiss, A. Guenbour, E.M. Essassi, H. Oudda, Corrosion inhibition of carbon steel in $1 \mathrm{M} \mathrm{HCl}$ by 1,5 benzodiazepine derivative: experimental and molecular modeling studies, J. Mater. Environ. Sci. 8 (2017) 2161-2173.

[10] F. Bentiss, M. Traisnel, N. Chaibi, B. Mernari, H. Vezin, M. Lagrenee, 2, 5-Bis (nmethoxyphenyl)-1, 3, 4-oxadiazoles used as corrosion inhibitors in acidic media: correlation between inhibition efficiency and chemical structure, Corros. Sci. 44 (2002) 2271-2289.

[11] M. El Azhar, B. Mernari, M. Traisnel, F. Bentiss, M. Lagrenee, Corrosion inhibition of mild steel by the new class of inhibitors [2, 5-bis (n-pyridyl)-1, 3, 4-thiadiazoles] in acidic media, Corros. Sci. 43 (2001) 2229-2238.

[12] L. Elkadi, B. Mernari, M. Traisnel, F. Bentiss, M. Lagrenee, The inhibition action of 3, 6-bis (2-methoxyphenyl)-1, 2-dihydro-1, 2, 4, 5-tetrazine on the corrosion of mild steel in acidic media, Corros. Sci. 42 (2000) 703-719.

[13] F. Bentiss, M. Bouanis, B. Mernari, M. Traisnel, M. Lagrenee, Effect of iodide ions on corrosion inhibition of mild steel by 3, 5-bis (4-methylthiophenyl)-4H-1, 2, 4-triazole in sulfuric acid solution, J. Appl. Electrochem. 32 (2002) 671-678.

[14] S. Rajendran, B.V. Apparao, N. Palaniswamy, Synergistic and antagonistic effects existing among polyacrylamide, phenyl phosphonate and Zn $2+$ on the inhibition of corrosion of mild steel in a neutral aqueous environment, Electrochim. Acta 44 (1998) 533-537.

[15] E.E. Ebenso, Synergistic effect of halide ions on the corrosion inhibition of aluminium in H 2 SO 4 using 2-acetylphenothiazine, Mater. Chem. Phys. 79 (2003) $58-70$.

[16] B. El Makrini, H. Lgaz, K. Toumiat, R. Salghi, S. Jodeh, G. Hanbali, M. Belkhaouda, M. Zougagh, Adsorption and corrosion-inhibiting effect of 5-Benzyloxy-6-methoxyindole on mild steel surface in hydrochloric acid solution: Electrochemical and Monte Carlo simulation studies, Res. J. Pharm. Biol. Chem. Sci. 7 (2016) 2277-2285.

[17] H. Lgaz, A. Anejjar, R. Salghi, S. Jodeh, M. Zougagh, I. Warad, M. Larouj, P. Sims, Characterization of corrosion products formed on carbon steel in hydrochloric acid medium by 4-(dimethylamino)-1-(6-methoxy-6-oxohexyl)pyridinium bromide, Int J. Corros. Scale Inhib. 5 (2016) 209-231.

[18] B. El Makrini, K. Toumiat, H. Lgaz, R. Salghi, S. Jodeh, G. Hanbali, M. Belkhaouda, M. Zougagh, Corrosion protection of mild steel in hydrochloric acid solutions in presence of 5-(Benzyloxy)indole - Monte Carlo simulation, weight loss and electrochemical studies, Res. J. Pharm. Biol. Chem. Sci. 7 (2016) 2286-2294.

[19] H. Lgaz, R. Salghi, K. Subrahmanya Bhat, A. Chaouiki, Shubhalaxmi, S. Jodeh, Correlated experimental and theoretical study on inhibition behavior of novel quinoline derivatives for the corrosion of mild steel in hydrochloric acid solution, $\mathrm{J}$. Mol. Liq. 244 (2017) 154-168, https://doi.org/10.1016/j.molliq.2017.08.121.

[20] H. Lgaz, R. Salghi, S. Jodeh, B. Hammouti, Effect of clozapine on inhibition of mild steel corrosion in 1.0M HCl medium, J. Mol. Liq. 225 (2017) 271-280, https://doi. org/10.1016/j.molliq.2016.11.039.

[21] M. Messali, H. Lgaz, R. Dassanayake, R. Salghi, S. Jodeh, N. Abidi, O. Hamed, Guar gum as efficient non-toxic inhibitor of carbon steel corrosion in phosphoric acid medium: electrochemical, surface, DFT and MD simulations studies, J. Mol. Struct 1145 (2017) 43-54, https://doi.org/10.1016/j.molstruc.2017.05.081.

[22] R. Wu, X. Qiu, Y. Shi, M. Deng, Molecular dynamics simulation of the atomistic monolayer structures of N-acyl amino acid-based surfactants, Mol. Simul. 43 (2017) 491-501.

[23] A.D. Becke, Density-functional exchange-energy approximation with correct asymptotic behavior, Phys. Rev. A 38 (1988) 3098-3100, https://doi.org/10.1103/ PhysRevA.38.3098.

[24] C. Lee, W. Yang, R.G. Parr, Development of the Colle-Salvetti correlation-energy formula into a functional of the electron density, Phys. Rev. B 37 (1988) 785-789, https://doi.org/10.1103/PhysRevB.37.785.

[25] Z. Salarvand, M. Amirnasr, M. Talebian, K. Raeissi, S. Meghdadi, Enhanced corrosion resistance of mild steel in $1 \mathrm{M} \mathrm{HCl}$ solution by trace amount of 2-phenyl-benzothiazole derivatives: experimental, quantum chemical calculations and molecula dynamics (MD) simulation studies, Corros. Sci. 114 (2017) 133-145.

[26] M. Gholami, I. Danaee, M.H. Maddahy, M. RashvandAvei, Correlated ab initio and electroanalytical study on inhibition behavior of 2-mercaptobenzothiazole and its thiole-thione tautomerism effect for the corrosion of steel (API 5L X52) in sulphuric acid solution, Ind. Eng. Chem. Res. 52 (2013) 14875-14889.

[27] R.G. Pearson, Absolute electronegativity and hardness: application to inorganic chemistry, Inorg. Chem. 27 (1988) 734-740.

[28] V. Sastri, J. Perumareddi, Molecular orbital theoretical studies of some organic corrosion inhibitors, Corrosion 53 (1997) 617-622.

[29] S. Martinez, Inhibitory mechanism of mimosa tannin using molecular modeling and substitutional adsorption isotherms, Mater. Chem. Phys. 77 (2003) 97-102.

[30] Z. Cao, Y. Tang, H. Cang, J. Xu, G. Lu, W. Jing, Novel benzimidazole derivatives as corrosion inhibitors of mild steel in the acidic media. Part II: theoretical studies, Corros. Sci. 83 (2014) 292-298.

[31] A. Kokalj, On the HSAB based estimate of charge transfer between adsorbates and metal surfaces, Chem. Phys. 393 (2012) 1-12.

[32] M. Frisch, G. Trucks, H.B. Schlegel, G. Scuseria, M. Robb, J. Cheeseman, G. Scalmani, V. Barone, B. Mennucci, G. Petersson, Gaussian 09, Revision D 01 (2009).

[33] S.K. Saha, M. Murmu, N.C. Murmu, P. Banerjee, Evaluating electronic structure of quinazolinone and pyrimidinone molecules for its corrosion inhibition effectivenes on target specific mild steel in the acidic medium: a combined DFT and MD simulation study, J. Mol. Liq. 224 (2016) 629-638.

[34] S. Kaya, B. Tüzün, C. Kaya, I.B. Obot, Determination of corrosion inhibition effects of amino acids: quantum chemical and molecular dynamic simulation study, J. Taiwan Inst. Chem. Eng. 58 (2016) 528-535, https://doi.org/10.1016/j.jtice.2015 06.009.

[35] K. Khaled, A. El-Maghraby, Experimental, Monte Carlo and molecular dynamics simulations to investigate corrosion inhibition of mild steel in hydrochloric acid solutions, Arab. J. Chem. 7 (2014) 319-326.

[36] I.A. Ammar, F.M. El Khorafi, Adsorbability of thiourea on iron cathodes, Mater. Corros. 24 (1973) 702-707.

[37] L. Larabi, Y. Harek, Effect of iodide ions on corrosion inhibition of mild steel in $0.5 \mathrm{M}$ H2SO 4 by poly (4-Vinylpyridine), Port. Electrochimica Acta 22 (2004) $227-247$.

[38] B. Xu, Y. Liu, X. Yin, W. Yang, Y. Chen, Experimental and theoretical study of corrosion inhibition of 3-pyridinecarbozalde thiosemicarbazone for mild steel in hydrochloric acid, Corros. Sci. 74 (2013) 206-213.

[39] B. Xu, W. Yang, Y. Liu, X. Yin, W. Gong, Y. Chen, Experimental and theoretical 
evaluation of two pyridinecarboxaldehyde thiosemicarbazone compounds as corrosion inhibitors for mild steel in hydrochloric acid solution, Corros. Sci. 78 (2014) 260-268.

[40] K. Ansari, D.K. Yadav, E.E. Ebenso, M. Quraishi, Novel and effective pyridyl substituted 1, 2, 4-triazole as corrosion inhibitor for mild steel in acid solution, Int. J. Electrochem. Sci. 7 (2012) 4780-4799.

[41] E.E. Oguzie, B.N. Okolue, E.E. Ebenso, G.N. Onuoha, A.I. Onuchukwu, Evaluation of the inhibitory effect of methylene blue dye on the corrosion of aluminium in hydrochloric acid, Mater. Chem. Phys. 87 (2004) 394-401.

[42] G. Mu, X. Li, G. Liu, Synergistic inhibition between tween 60 and $\mathrm{NaCl}$ on the corrosion of cold rolled steel in 0.5M sulfuric acid, Corros. Sci. 47 (2005) 1932-1952.

[43] H. Keleș, M. Keleș, I. Dehri, O. Serindağ, The inhibitive effect of 6-amino-m-cresol and its Schiff base on the corrosion of mild steel in 0.5M HCI medium, Mater. Chem. Phys. 112 (2008) 173-179.

[44] M. Stern, A.L. Geary, Electrochemical polarization I. A theoretical analysis of the shape of polarization curves, J. Electrochem. Soc. 104 (1957) 56-63.

[45] W. Li, Q. He, S. Zhang, C. Pei, B. Hou, Some new triazole derivatives as inhibitors for mild steel corrosion in acidic medium, J. Appl. Electrochem 38 (2008) 289-295.

[46] X. Li, S. Deng, H. Fu, Synergism between red tetrazolium and uracil on the corrosion of cold rolled steel in $\mathrm{H}_{2} \mathrm{SO}_{4}$ solution, Corros. Sci. 51 (2009) 1344-1355.

[47] H.J.W. Lenderink, M.V.D. Linden, J.H.W. De Wit, Corrosion of aluminium in acidic and neutral solutions, Electrochimica Acta 38 (1993) 1989-1992.

[48] C. Verma, M. Quraishi, A. Singh, 2-Amino-5-nitro-4, 6-diarylcyclohex-1-ene-1, 3, 3tricarbonitriles as new and effective corrosion inhibitors for mild steel in $1 \mathrm{M} \mathrm{HCl}$ : experimental and theoretical studies, J. Mol. Liq. 212 (2015) 804-812.

[49] D.K. Singh, S. Kumar, G. Udayabhanu, R.P. John, 4 (N, N-dimethylamino) benzaldehyde nicotinic hydrazone as corrosion inhibitor for mild steel in $1 \mathrm{M} \mathrm{HCl}$ solution: an experimental and theoretical study, J. Mol. Liq. 216 (2016) 738-746.

[50] A. Popova, E. Sokolova, S. Raicheva, M. Christov, AC and DC study of the temperature effect on mild steel corrosion in acid media in the presence of benzimidazole derivatives, Corros. Sci. 45 (2003) 33-58.

[51] M. Gojić, The effect of propargylic alcohol on the corrosion inhibition of low alloy CrMo steel in sulphuric acid, Corros. Sci. 43 (2001) 919-929.

[52] H. Lgaz, R. Salghi, S. Jodeh, B. Hammouti, Effect of clozapine on inhibition of mild steel corrosion in 1.0M HCl medium, J. Mol. Liq. 225 (2017) 271-280.
[53] W. Chen, S. Hong, B. Xiang, H. Luo, M. Li, N. Li, Corrosion inhibition of copper in hydrochloric acid by coverage with trithiocyanuric acid self-assembled monolayers, Corros. Eng. Sci. Technol. 48 (2013) 98-107.

[54] S. Martinez, M. Metikoš-Huković, A nonlinear kinetic model introduced for the corrosion inhibitive properties of some organic inhibitors, J. Appl. Electrochem. 33 (2003) 1137-1142.

[55] R.A. Prabhu, T.V. Venkatesha, A.V. Shanbhag, G.M. Kulkarni, R.G. Kalkhambkar, Inhibition effects of some Schiff's bases on the corrosion of mild steel in hydrochloric acid solution, Corros. Sci. 50 (2008) 3356-3362.

[56] E.E. Oguzie, V.O. Njoku, C.K. Enenebeaku, C.O. Akalezi, C. Obi, Effect of hexamethylpararosaniline chloride (crystal violet) on mild steel corrosion in acidic media, Corros. Sci. 50 (2008) 3480-3486.

[57] H. Freundlich, Über die adsorption in lösungen, Z. Für Phys. Chem. 57 (1907) $385-470$.

[58] D. Landolt, Corrosion Et Chimie De Surface Des Metaux, Alden, Oxford, 1993.

[59] S.O. Adejo, M.M. Ekwenchib, J.A. Gbertyoa, T. Menengea, J.O. Ogbodoc, Determination of adsorption Isotherm model best fit for methanol leaf extract of Securinega virosa as corrosion inhibitor for corrosion of mild steel in HCl, J. Adv. Chem. 10 (2014).

[60] R. Salghi, S. Jodeh, E.E. Ebenso, H. Lgaz, D. Ben Hmamou, M. Belkhaouda, I.H. Ali, M. Messali, B. Hammouti, S. Fattouch, Inhibition of C-steel corrosion by green tea extract in hydrochloric solution, Int. J. Electrochem. Sci. 12 (2017) 3283-3295, https://doi.org/10.20964/2017.04.46.

[61] S.S. El-Egamy, Corrosion and corrosion inhibition of $\mathrm{Cu}-20 \% \mathrm{Fe}$ alloy in sodium chloride solution, Corros. Sci. 50 (2008) 928-937.

[62] K. Aramaki, N. Hackerman, Inhibition mechanism of medium-sized polymethyleneimine, J. Electrochem. Soc. 116 (1969) 568-574.

[63] R. Kumar, S. Chahal, S. Kumar, S. Lata, H. Lgaz, R. Salghi, S. Jodeh, Corrosion inhibition performance of chromone-3-acrylic acid derivatives for low alloy steel with theoretical modeling and experimental aspects, J. Mol. Liq. 243 (2017) 439-450, https://doi.org/10.1016/j.molliq.2017.08.048.

[64] Z. Zhang, N.C. Tian, X.D. Huang, W. Shang, L. Wu, Synergistic inhibition of carbon steel corrosion in $0.5 \mathrm{M} \mathrm{HCl}$ solution by indigo carmine and some cationic organic compounds: experimental and theoretical studies, RSC Adv. 6 (2016) 22250-22268, https://doi.org/10.1039/C5RA25359D. 